\title{
Does Capital Flight Harm Domestic Investment? An Empirical Investigation from a Panel of Emerging and Advanced Europe ${ }^{1}$
}

Menbere WORKIE TIRUNEH* - Maria SIRANOVA** - Filip OSTRIHON**

\begin{abstract}
In this study, we estimate the size of capital flight and its spillover effect on domestic investment in selected European economies during the 2006 - 2016 period. The results based on the fixed effects ordinary least squares method suggest that capital flight has an adverse impact on investment in the economies included in our sample. As a robustness check, we also use the system generalized method of moments (GMM). Our results based on a mix of emerging and advanced economies are fairly similar with previous studies based on emerging economies alone (Yalta, 2010) and developing economies (Ndiaye, 2009).
\end{abstract}

Keywords: capital flight, investment, OLS, GMM

JEL Classification: C23, F43, O47

DOI: https://doi.org/10.31577/ekoncas.2021.02.02

\section{Introduction}

As pointed out by Cerra, Rishi and Saxena (2005), capital flight has been integrated into the development economics literature, as it has generally been considered harmful to investment and economic growth. While previous studies recognize the adverse impact of capital flight on economic growth, most of the

\footnotetext{
* Menbere WORKIE TIRUNEH, Institute of Economic Research, Slovak Academy of Sciences, Šancová 56, 81105 Bratislava, Slovak Republic; Webster Vienna, Private University, Praterstrasse 23, 1020 Vienna, Austria; e-mail: menbere.workie@webster.ac.at

** Maria SIRANOVA - Filip OSTRIHON, Institute of Economic Research, Slovak Academy of Sciences, Šancová 56, 81105 Bratislava, Slovak Republic; e-mail: maria.siranova@ savba.sk; filip.ostrihon@savba.sk

${ }^{1}$ This paper was supported by the Slovak Research and Development Agency under contracts No. APVV-15-0666: Capital Flight and its Impact on the Slovak Economy. Siranova acknowledges that this paper is the partial result of the project VEGA under Grant No. 2/0101/21.

We thank Jarko Fidrmuc and two anonymous referees for their helpful comments and suggestions.
} 
focus has revolved around developing countries in Africa and Latin America in the 1980s and 1990s. The last two decades of the 21st century were indeed a development disaster for most developing nations, mainly due to mounting external debt coupled with the exodus of capital from these regions (Kant, 1996; Ajayi, 1997; Schneider, 2003; Hermes and Lensink, 2001; Fofack and Ndikumana, 2010). The Global Financial Integrity (GFI) annual report on illicit capital flows seems to confirm the existence of increasing pressure of capital flight from the developing and emerging parts of the world (GFI, 2017). In this regard, there is a great deal of literature on measurement issues and the key macroeconomic determinants of capital flight, despite the absence of a common theoretical framework of what exactly capital flight is and the corresponding methodological bottlenecks on how it should be estimated.

In his seminal work based on the Lane and Milesi-Ferretti (2007) database on the external wealth of nations, Zucman (2013) estimated that approximately 8\% of the global financial wealth of households has been held in tax havens and that a significant proportion of this wealth has gone missing. The study also shows that the global financial data do not add up from two perspectives. First, liabilities exceed assets for the global economy as a whole. Second, based on balanceof-payments data, it has been detected that "more investment income is paid than received each year" at a global level. An alarming piece of evidence from our study's perspective is that the findings indicate a significant proportion of European securities have "no identifiable owner".

Against this background, there is an ongoing quest to closely investigate both the magnitude and macroeconomic implications of such unrecorded financial flows in advanced economies. While a few studies focus on emerging economies (Perez, Brada and Drabek, 2012; Brada, Kutan and Vuksic, 2013; Yalta, 2010; and Yalta and Yalta, 2012; and Janský and Palansky, 2017 on a large of countries), there is no study that includes a large set of advanced economies in Europe.

In this study, we estimate the size of capital flight and its consequences for investment in selected European economies during the 2006 - 2016 period for which data are available. While unrecorded financial flows have been on the rise following the liberalization of the world economy since the mid-1990s, the task of estimating both the size of such financial flows and their possible adverse impact on the economies of advanced countries has been largely marginalized.

This gap remains despite the existence of both anecdotal evidence and empirical observations that advanced economies have experienced illicit financial flows of one form or another in recent decades. The recently leaked documents (the Luxembourg leaks or "LuxLeaks" of 2014, the Swiss leaks in 2015, the Panama Papers of 2016, and the Paradise Papers of 2018) that exposed the number 
of individuals and firms predominantly from advanced economies who have held their wealth in tax havens only confirm the severity of the problem related to illicit financial flows in advanced economies.

The remainder of the paper is divided as follows. The next part discusses conceptual and methodological issues regarding capital flight focusing on key previous empirical studies. Part three brings methods and sample of countries included in this study. Part four brings results and discussion and part five concludes.

\section{Literature Review}

On the theoretical front, definitions of capital flight are rather diverse and often unclear or conditional on the development stages of the countries studied (Hermes and Lensink, 2014). As Kanitz (1984) rightly asked, "why is it that when an American puts money abroad it is called 'foreign investment' and when an Argentinean does the same it is called 'capital flight'?" The central idea is to emphasize that the stage of economic development of a country is a fundamental criterion to determine whether capital outflows are condemned as abnormal (capital flight) or celebrated as normal (foreign investment). In this regard, while substantial progress has been achieved, the theoretical puzzle of when capital outflows constitute flight and what the macroeconomic ramifications of such outflows are remains.

Early studies emphasized the development stage of a country, arguing that any capital outflows from poor to rich countries should be considered abnormal and perverse (Tornell and Velasco, 1992; Ajayi, 1997). As argued in Hermes and Lensink (2001), countries with lower levels of income per capita and large current account deficits may find themselves under pressure in financing the deficits if they simultaneously face large capital outflows.

Other studies emphasize the role of uncertainty and political risks in defining capital outflows as capital flight. In such a context, capital flight is considered to be one-way net flows caused by political and economic uncertainties, resulting in the achievement of a real transfer (Kant, 1996; Varman-Schneider, 1991; Ajayi, 1997). Gunter (2008) defines capital flight as "an outflow of funds from a country motivated by an adverse change in the countries' economic, political or social environment". Similarly, Epstein (2005) underscores that capital flight is the transfer of assets abroad in an attempt to reduce the possibility of losses associated with principal payments, investment returns or control over an individual's financial wealth due to adverse government policies.

From a different perspective, resident capital outflows are considered a rational decision by the private sector seeking to diversify the amount of risk across different assets, including by holding assets abroad (Collier, Hoeffler and Pattillo, 
2001; Buiter and Szegvari, 2002; Epstein, 2005). Likewise, Pastor (1990) associates capital flight with wealthy citizens investing abroad by acquiring significant stocks of foreign assets, and Yalta and Yalta (2012) define capital flight as the process of unrecorded accumulation of foreign assets by the private sector.

As emphasized by Schneider (2003), however, such capital outflows in search of portfolio optimization may not necessarily be socially beneficial, as they reduce domestic investment and economic growth, eventually leading to welfare losses. The ramifications of capital flight for possible welfare loss have also been recognized by previous studies. Dooley and Kletzer (1994) lamented that capital flight reduces social welfare as households export capital for tax optimization purposes. There may also be other suspicious and obscured incentives behind private cash outflows that include but are not limited to money laundering and related criminal activities (Janský and Palansky, 2017; World Custom Organization, 2019). While the definitions so far emphasize the broader context of capital flight, other studies focus more on a narrow definition of the term, where short-term movement of capital across countries is taken as an indication of "illegal" or "speculative" capital outflows (Cuddington, 1986).

The absence of consensus on the concept of capital flight has also been exacerbated by the introduction of, at the first glance, a rival concept that has come to be known as illicit financial (capital) flows. Various annual reports from Global Financial Integrity define such flows as 'cross-border transfers of funds that are illegally earned, transferred or utilized'. The term encompasses a variety of practices, including trade mis-invoicing, cash smuggling, bank transfers disguised as foreign investment, tax evasion, criminal earnings, bribery, and corporate profit shifting, among others (Janský and Palansky, 2017; World Custom Organization, 2019). In an extreme way, Baker (2005, p. 23) defines such illicit financial flows as "dirty money" to imply "money that is illegally earned, illegally transferred, and illegally utilized". Similar to the concept of capital flight, illicit financial outflows are hidden under the curtain of economic and political uncertainty (Epstein, 2005).

\section{From High Capital Flight to Lower Domestic Investment: The Transmission Channels}

There is a sizable amount of literature focusing on four aspects of the phenomenon of capital flight. The first line of literature focuses mainly on estimating the magnitude and determinants of capital flight, often for individual countries or groups of developing or emerging economies (World Bank, 1985; Lessard and Williamson, 1987; Boyce and Ndikumana, 2001; 2018; Schneider, 2003; Hermes, Lensink and Murinde, 2002; Brada, Kutan and Vuksic, 2011; 2013; Yalta and 
Yalta, 2012; Ndikumana, Boyce and Ndiaye, 2014; Ndiaye, 2009). Not surprisingly, a significant proportion of the studies have focused on the developing world, with a handful of studies on Eastern European and some emerging economies in the 1990s.

The majority of the studies conclude that economic factors play a significant role in the evolution of capital flight in a sample of the economies considered. In a rare study of Central and Eastern Europe, Brada, Kutan and Vuksic (2011) found that liberalization of trade and the financial sector tuned out to be the main trigger. In contrast, Yalta and Yalta (2012), based on emerging economies, claims that financial liberalization policies do not play any crucial role in the impact of capital flight on investment. Antzoulatos and Sampaniotis (2002) explored the key determinants of capital flight in Eastern Europe during the 1990s. Their findings seem to suggest that a government budget deficit, overvalued currencies and inflation are plausible determinants of capital flight in their sample of countries during the period under investigation.

Some studies examined the determinants of capital flight targeting individual countries. Based on monthly and quarterly data during the $1999-2008$ period, Cheung and Qian (2010) found the interest rate differential to be the key determinant of capital flight in China. Another study on Hong Kong's capital flight phenomenon suggested currency overvaluation, the current account deficit and China's open door policy were the main triggers of capital flight (Han, et al., 2012). In a study targeting the Russian Federation, policy uncertainty and institutional weakness were considered to have contributed to a large amount of capital flight from Russia (Tikhomirov, 1997; Loungani and Mauro, 2000, and Siranova and Workie Tiruneh, 2017) showed that real transfers such as FDI and services played a significant role in determining the size of net errors and omissions, an indicator that is often used as a proxy for short-term and speculative capital flows.

Turning to the channels of capital outflow, there are several avenues for capital flight that may shackle the level of investment and economic development. In this regard, external debt buildup is often labelled as a leading suspect. This notion is based on the presumption that there exists a comovement of external debt and capital flight as higher capital flight erodes domestic investment and that, in response, countries should find replacement investment funds from abroad. Several studies claim that external debt has an adverse impact on economic growth and investment in developing countries (Pattillo, Poirsom and Ricci, 2002) and advanced economies (Checherita-Westphal and Rother, 2012). This impact applies to a rise in domestic public debt, which is often accompanied by the famous crowding-out effect. This effect is based on simple arithmetic, where more government borrowing from the banking industry would exhaust banks' 
abilities to lend to the private sector and lead to a lower supply of credit and higher interest rates. However, according to the Ricardian equivalence theorem, this exhaustion should not be the case, as government deficit financing either through borrowing or raising taxes would lead to the same (equivalent) outcome. Higher current government expenditure would lead individuals and firms to anticipate higher interest rates in the future, which increases the marginal propensity to save of the private sector so that it can pay higher interest rates and tax bills in the future (Barro, 1974). Higher current savings by the private sector would boost loanable funds in the banking industry, increasing the supply of loans and driving down interest rates, hence leaving the private sector unaffected (Barro, 1974).

Blankenburg and Khan (2012) emphasize the prevalence of a two-way capital flow involved in the presence of "odious debt" buildup that emerges if external debt by a government is turned into private sector wealth accumulation. Early studies, for instance Eaton (1987), argue that tax evasion harms not only current economic growth but also future growth by increasing debt service payments. This notion is in line with other studies showing that capital flight may hamper growth by increasing the marginal cost of debt (Edwards, 2001).

On the empirical front, some studies on developing countries indeed show such patterns. Chipalkatti and Rishi (2013) looked at the link between capital flight and debt in India. Their findings suggest that capital flight and debt were intertwined in India during the 1971 - 1997 period. Cerra, Rishi and Saxena (2005), based on a large set of developing countries (134) during the 1970 - 2001 period, underscored the role of poor institutional quality and ill-conceived economic policy as key determinants of capital flight. The study also showed the role of external debt in fostering capital flight in these economies. Ndikumana and Boyce (2011) investigated the size of capital flight based on the data of 33 African countries during the $1970-2014$ period and found that the magnitude of capital flight far outweighs the size of external debt, and in practice, this finding implies, surprisingly, that sub-Saharan Africa turned out be a net creditor vis-à-vis the rest of the world. However, studies also warned that capital flight is more of a symptom than the cause of high debt and low investment and growth (Dornbusch, 1987; Sachs, 1986).

An equally important channel through which capital flight could drag down investment and economic growth comes via erosion of the tax base. It is argued that unrecorded capital that exits a country remains out of the reach of local tax authorities (Pastor, 1990, Ajayi, 1997; Collier, Hoeffler and Pattillo, 2001; Ayadi, 2008; Forgha, 2008; Ndikumana and Boyce, 2011; Ndikumana, Boyce and Ndiaye, 2014). The decline in taxable income reduces the ability of a government to collect taxes and reduces the resources to finance government expenditure, 
thus leading to sluggish investment and growth (Forgha, 2008). Such a "fiscal shock" may put a government under pressure to increase taxes on domestic investors, reducing their expected rate of return on domestic asset holdings and eventually triggering residents to hold foreign assets (Dooley and Kletzer, 1994).

Janský and Palansky (2017) conducted an extensive study on the macroeconomic repercussions of illicit financial flows based on a sample of a large set of developed and developing countries. Their findings imply that there is a sizable volume of tax evasion by multinational corporations resulting in tax revenue losses. The findings also emphasize that poorer countries are by far worse off compared to their wealthier counterparts as far as revenue losses are concerned and that this condition eventually contributes to a widening of the scale of income polarization in the world.

The third channel of capital flight (illicit financial flows) is foreign direct investment (FDI). While FDI has been celebrated as the main accelerator of growth and a vehicle of technological and know-how diffusion, it has also been under suspicion for serving as an outlet for illicit financial flows. In one of the first related studies and based on the data of several heterogeneous regions during the 1974 - 1992 period, Kant (1996) showed that the size of foreign direct investment contributes to triggering capital flight in all observations and time periods. In a more recent study, Perez, Brada and Drabek (2012) examined the perverse nature of FDI and postulated that FDI serves as a vehicle to facilitate illicit financial flows. Their findings seem to suggest that a significant level $(6-10 \%)$ of total FDI outflows, and over $20 \%$ of FDI to money-laundering countries from the sample, was to facilitate illicit money flows. The link between foreign direct investment and illicit financial flows in developing economies has also been the subject of empirical studies. Based on a sample of African countries, Ndikumana and Sarr (2019) showed that there is a positive relationship between FDI and capital flight, signalling the prevalence of "FDI-fuelled" capital flight.

The fourth strand of the literature focuses on the direct consequences of capital flight on investment, which is considered the main driver of economic growth. In their famous study based on a sensitivity analysis, Levine and Renelt (1992) demonstrated that investment is the most robust and plausible source of economic growth (Levine and Renelt, 1992).

The role of investment in economic growth is related to the neoclassical growth framework, which postulates the valuable role of investment and technology in the growth process. The policy implication of the neoclassical model is rather straightforward. With diminishing returns to investment, all else equal, capital should move from countries with a higher capital-to-output ratio, where the marginal product of capital is lower, to countries where the capital-to-labour 
ratio is lower and, hence, the marginal product of capital is higher (Solow, 1956; Mankiw, Romer and Weil, 1992). In the presence of capital flight, investment is affected directly by reducing the capital-to-labour ratio in relatively capital-scarce economies. Capital flight is also argued to adversely affect the level of domestic investment by reducing domestic savings (Ndiaye, 2009).

However, there are at least two limitations to the assumptions of the neoclassical model and capital mobility across countries or regions. First, the concept of the capital-to-labour ratio is associated with the overall rate of return, while private portfolio decisions are a function of other factors, such as interest rates and taxes (Collier, Hoeffler and Pattillo, 2001). Second, as argued by Lucas (1990), in the presence of human capital and institutional variations among poor and rich economies and imperfect financial markets, more capital and goods should still move from poor to rich economies, often referred to as uphill flows or the Lucas paradox. In this regard, Fidrmuc, Hake and Stix (2013) based data of Central and Easter European economies; conclude that foreign borrowing by households reflects the mistrust in local currencies as well as lack of confidence in the domestic financial institutions.

In a comprehensive empirical study based on the sample of francophone economies during the 1970 - 2010 period, Ndiaye (2009) shows both the scale and adverse impact of capital flight on investment and economic growth in these economies. While most of the empirical studies on capital flight and growth are based on individual countries in Africa (Fedderke and Liu, 2002; Fofack and Ndikumana, 2009; 2010; Ayadi, 2008), other studies take on other regions (Greene, 2002, on Asian economies; Yalta, 2010, on emerging economies; and Cheung and Qian, 2010, on China's experience). The common denominator of these studies is the recognition that capital flight indeed hampers economic growth by reducing the level of investment.

\section{Methods of Estimating the Stock of Capital Flight}

Estimating unrecorded capital flows (capital flight|) across countries is undoubtedly a difficult task, as a significant portion of such unrecorded financial flows are systematically obscured. However, there are several methods to estimate the size of capital flight, albeit with drawbacks and controversies.

\section{World Bank Residual Method}

The residual method, which is also known as the World Bank method, of estimating capital flight has been the most widely used method (World Bank, 1985) and takes the difference between the sources of funds and uses of funds. 
The equation, which is derived from the balance of payments, is approximated as follows:

$$
\mathrm{CF}=[\Delta \mathrm{ED}+\mathrm{FDI}]-[\mathrm{CA}+\Delta \mathrm{R}]
$$

where $\mathrm{CF}$ stands for capital, $\triangle \mathrm{ED}$ indicates the change in external debt, FDI indicates net foreign direct investment, CA indicates the current account deficit, and $\Delta \mathrm{R}$ indicates the change in international reserves. The model is based on the current account and capital account items that keep the balance of payments of a country balanced. In this model, the recorded sources of funds are compared with the recorded uses of funds. If the sources of funds exceed the uses of funds, illicit capital flows (capital flight) will emerge. While this is the most widely used method to estimate capital flight, the method is far from perfect due, for example, to its upwards bias as an estimator of capital flight (Collier, Hoeffler and Pattillo, 2001; Cobham and Janský, 2017; GFI, 2010). However, the residual method is most preferred for its broad coverage and intuitive nature, minimizing the scope of potential biases in narrower measures and possible replications (Cheung and Qian, 2010; Quan and Rishi, 2006).

\section{Net Errors and Omission - 'Hot Capital Flows'}

Net errors and omissions (NEO) is a narrow measure of capital flight that allows the sum of net short-term capital outflows plus net errors and omissions in the balance-of-payments statistics. According to Edwards (1989), if short-term capital outflows are not available, quite a reasonable approximation can be obtained if net errors and omissions are taken alone to measure capital flight. Hence, short-term speculative capital flows can be measured by the size of errors and omissions (NEO) in the balance of payments with the opposite sign compared to what is reported in the IMF balance-of-payments statistics (Cuddington, 1986). The "hot capital flows" approach approximated by NEO volumes, referred to as 'balance-of-payments leakages', is regularly applied by the Global Financial Integrity reports estimating the extent of the capital flight phenomenon in developing countries. All the dollar values have been converted into Euro using the official exchange.

\section{Empirical Methodology and Data Description}

Motivated by the availability of data for particular countries, we use a sample consisting of 35 countries, of which 28 are members of the European Union. Due to limited availability of data for external debt and other balance-of-payments indicators, our data cover the 2006 - 2016 period. 
Our dependent variable is gross fixed capital formation, and we follow previous empirical specifications on investment (Checherita-Westphal and Rother, 2012; Yalta, 2010).

List of variables are Data Availability Information are included in Table (1).

Table 1

List of Variables Included in the Regression

\begin{tabular}{|l|l|l|}
\hline Variable & \multicolumn{1}{|c|}{ Description } & \multicolumn{1}{|c|}{ Source } \\
\hline Investment & Gross fixed capital formation (\% of GDP) & World Bank \\
$\mathrm{NeO}$ & Net Errors and Omissions (\% of GDP) & World Bank \\
$\mathrm{RES}$ & Capital flight based residual model (\% GDP) & \\
Open & Export plus import (\% of GDP) & World Bank \\
GDP P.C growth & Growth rate of real GDP per capita & World Bank \\
Gov. Debt & Government Debt (\% of GDP) & World Bank \\
Interest rate & Real interest rate & World Bank \\
ROL & Rule of Law (deviation from the mean) & World Bank \\
KA OP & Capital account openness & Chinn-Ito database \\
Priv. credit & Bank credit to the private sector (\% of GDP) & World Bank \\
Gov. cons & Total government consumption (\% of GDP) & World Bank \\
\hline
\end{tabular}

Source: Authors' compilation of the list based on data from the World Bank and Chinn-Ito database.

$$
\begin{aligned}
& \operatorname{Inv}_{\mathrm{it}}=\beta_{0}+\beta_{1} \operatorname{Inv}_{\mathrm{it}-1}+\beta_{2} \mathrm{CFL}_{\mathrm{it}-1}+\beta_{3} \Delta \ln \left(\mathrm{Y}_{\mathrm{it}}\right)+\beta_{4} \mathrm{GGD}_{\mathrm{it}}+\beta_{5} \operatorname{Int}_{-} \text {rate }_{\mathrm{it}}+ \\
& +\beta_{6} \text { Open }_{\mathrm{it}}+\gamma \mathrm{Z}_{\mathrm{it}}+\mathrm{u}_{\mathrm{i}}+\mathrm{v}_{\mathrm{t}}+\varepsilon_{\mathrm{it}}
\end{aligned}
$$

In equation [2], $\operatorname{Inv}_{\text {it }}$ is the amount of gross fixed capital formation as a share of nominal GDP $\left(\mathrm{y}_{\mathrm{it}}\right), \mathrm{CFL}_{\mathrm{it}}$ is the amount of capital flight as a share of nominal GDP, $\Delta \ln \left(Y_{\text {it }}\right)$ represents GDP per capita growth (to capture the accelerator effect on investment), $G_{G D}$ it is gross government debt as a share of nominal GDP (to control for the famous revolving door effect), Int_rate it $_{\text {it }}$ is the real interest rate (to measure the cost of capital, as higher interest rates, all else constant, should lead to lower investment), Open ${ }_{\text {it }}$ is the sum of import and export expressed as a share of nominal GDP, $u_{i}$ is time-invariant country-specific fixed effects, $v_{t}$ is a timespecific fixed effect, and $\varepsilon_{\mathrm{it}}$ is the idiosyncratic error.

Both $\mathrm{CFL}_{\mathrm{it}}$ and $\mathrm{Inv}_{\mathrm{it}}$ are lagged by one period, as these variables are expected to have longer-term (more persistent) effects. Studies claim that past capital flight is likely to trigger future capital flight (Collier, Hoeffler and Pattillo, 2001). The vector of additional control variables $\left(\mathrm{Z}_{\mathrm{it}}\right)$ includes financial liberalization, the rule of law, government consumption and interaction terms of capital flight with the policy variables (financial liberalization and the rule of law). We include financial liberalization proxied by the degree of capital account control (KAOP) as in Yalta and Yalta (2012) and Hermes and Lensink (2014) to control for the degree of financial liberalization using the Chinn-Ito database (2017). In their study, Hermes and Lensink (2014) showed that financial liberalization does not play 
a favourable role in enhancing public investment, but they conclude that it fosters private investment. Likewise, Yalta and Yalta (2012) did not find any vital role played by financial liberalization in triggering capital flight. For obvious reasons, we also include a policy variable proxied by the rule of law index taken from the World Bank database (World Bank, 2019). Following a panel data analysis of corruption and capital flight, Le and Rishi (2006), Le and Zal (2006) demonstrated that there is a positive and significant effect of corruption on capital flight.

Due to the unavailability of compatible data, our empirical exercise did not decompose total fixed capital formation into public and private investment, something we consider essential for future investigation once such data become available. All of the variables included in the study were obtained from publicly accessible sources. The list of all included variables and countries in our sample is provided in Table 1 and Table 4, respectively. Capital flight, investment and external debt are used as a ratio of GDP to account for size variations across countries.

To estimate the impact of capital flight on investment [2], we use two alternative measures of capital flight: (a) the measure based on the net errors and omissions item from the balance-of-payments statistics and (b) the residual approach measure estimated based on the World Bank's residual model (World Bank, 1985). The presented models of the effect of capital flight on investment were estimated using both panel fixed effects (FE) ordinary least squares (OLS) and system generalized method of moments (GMM) estimators. The FE OLS model serves as our main empirical specification. For a robustness check, we also use GMM to address potential bias stemming from the use of country-specific fixed effects and lagged dependent variables as a regressor (Roodman, 2009). Given the changing nature of the global economic landscape resulting from the global financial crisis, period dummies were included in each regression.

The statistical significance of the estimated parameters was assessed based on t-statistics with the use of cluster-robust standard errors in the case of the FE OLS specification and the corresponding two-step covariance matrix adjusted by Windmeijer's finite-sample correction in the case of system GMM. As part of the verification procedure, the Arellano-Bond test for first- and second-order autocorrelation of the differenced residuals is reported. Furthermore, the Sargan test statistic of over-identifying restrictions is provided. However, this statistic is not robust to heteroscedasticity and autocorrelation possibly featured in the residuals. Therefore, the Hansen J-statistic is also reported, which is robust to the previously mentioned issues but may be subject to potential instrument proliferation (Roodman, 2009). The assumption of weak cross-sectional dependence (CS DEP) was tested in both the FE OLS and system GMM models using the Chudik and Pesaran (2015) test statistic, which was implemented in Stata by Ditzen (2016). 


\section{Results and Discussion}

When examining the relationship between investment and capital flight (based on equation 2) for a large set of European economies, the results appear to be consistent regardless of whether net errors and omissions (Figure 1) or the computed residual model (Figure 2) is used as the measure of capital flight. The corresponding marginal effects are generally negative and largely statistically significant, hinting that capital flight exerts an adverse impact on the level of investment in these economies. Although the marginal effects are negative in all specifications, they all remain statistically insignificant when we use trade mis-invoicing as a proxy for capital flight for our sample. These results are not reported in the paper but are available upon request.

The variables included in our estimation and the corresponding sources are in Table 1. The results are presented in four tables. Table 2 a presents the marginal effects of capital flight on investment using net errors and omissions as a proxy for capital flight. In this specification, as in the other three tables, the first column is the baseline regression. The results based on ordinary least squares with fixed effects suggest that the lag of capital flight negatively and statistically significantly correlates with investment, except for when it interacts with financial market liberalization (KAOP), where the interaction term becomes negative and statistically significant.

This outcome suggests that higher capital flight exerts a higher adverse impact on the level of investment in economies with a higher scale of openness. Our results deviate from previous results, where financial liberalization did not seem to play any major role (Yalta and Yalta, 2012). This deviation may be due to both differences among advanced and emerging economies and the time of observation. In our specification, we also use the rule of law (ROL) as an additional policy variable to assess whether policy matters in measuring the impact of capital flight on investment. Unlike financial liberalization (KAOP), the marginal effects of ROL or the interaction term (CFL*ROL) did not yield any statistically significant relationship with investment, although the signs remain negative. The autoregressive term is consistently statistically significant and positive in all specifications.

Turning to other variables, the coefficient on GDP per capita growth, used as a proxy to capture the accelerator effect, is positive and statically significant, suggesting that higher economic growth fosters domestic investment. As one would expect, the real interest rate has a negative and statistically significant relationship with the level of investment, suggesting that a higher real interest rate could have a detrimental effect on investment. The marginal effect of external debt on domestic investment is negative and statistically significant, despite being of smaller scale. This outcome suggests that higher external debt in fact 
reduces the level of domestic investment, which is in contrast to the hypothesized revolving door effect, which has been proven to be present in other developing countries (Boyce and Ndikumana, 2001).

$\mathrm{T}$ a b le $2 \mathrm{a}$

The Effect of Capital Flight (Proxied by Neo) on Total Investment: FE OLS

\begin{tabular}{|c|c|c|c|c|c|c|c|}
\hline Investment & (1) & (2) & (3) & (4) & (5) & (6) & (7) \\
\hline $\operatorname{NEO}(-1)$ & $\begin{array}{r}-0.116^{*} \\
(0.090) \\
\end{array}$ & $\begin{array}{c}-0.116^{*} \\
(0.096) \\
\end{array}$ & $\begin{array}{c}-0.079 \\
(0.258)\end{array}$ & $\begin{array}{c}-0.099 \\
(0.168) \\
\end{array}$ & $\begin{array}{r}-0.131 * \\
(0.097) \\
\end{array}$ & $\begin{array}{r}-0.116^{*} \\
(0.091) \\
\end{array}$ & \begin{tabular}{|l}
-0.064 \\
$(0.345)$ \\
\end{tabular} \\
\hline Investment (-1) & $\begin{array}{l}0.655^{* * *} \\
(0.000)\end{array}$ & $\begin{array}{l}0.654 * * * \\
(0.000)\end{array}$ & $\begin{array}{l}0.655^{* * * *} \\
(0.000)\end{array}$ & $\begin{array}{l}0.648^{* * * *} \\
(0.000)\end{array}$ & $\begin{array}{l}0.633^{* * *} \\
(0.000)\end{array}$ & $\begin{array}{l}0.654 * * * \\
(0.000) \\
\end{array}$ & $\begin{array}{l}0.658^{* * * *} \\
(0.000)\end{array}$ \\
\hline Open & $\begin{array}{c}0.002 \\
(0.823) \\
\end{array}$ & $\begin{array}{c}0.002 \\
(0.823) \\
\end{array}$ & $\begin{array}{c}-0.001 \\
(0.937) \\
\end{array}$ & $\begin{array}{c}0.006 \\
(0.609) \\
\end{array}$ & $\begin{array}{c}0.001 \\
(0.941) \\
\end{array}$ & $\begin{array}{c}0.002 \\
(0.820) \\
\end{array}$ & \begin{tabular}{|c|}
-0.005 \\
$(0.771)$ \\
\end{tabular} \\
\hline GDP p.c. growth & $\begin{array}{l}0.377 * * * \\
(0.000)\end{array}$ & $\begin{array}{l}0.377 * * * \\
(0.000)\end{array}$ & $\begin{array}{l}0.399 \text { *** } \\
(0.000)\end{array}$ & $\begin{array}{l}0.348^{* * * *} \\
(0.000)\end{array}$ & $\begin{array}{l}0.358^{* * *} * \\
(0.000)\end{array}$ & $\begin{array}{c}0.377 * * * \\
(0.000)\end{array}$ & $\begin{array}{l}0.400^{* * * *} \\
(0.000)\end{array}$ \\
\hline Gov. Debt & $\begin{array}{c}-0.024 * * \\
(0.025)\end{array}$ & $\begin{array}{c}-0.024 * * \\
(0.026)\end{array}$ & $\begin{array}{c}-0.025 * * \\
(0.021)\end{array}$ & $\begin{array}{c}-0.023^{* *} * \\
(0.044)\end{array}$ & $\begin{array}{r}-0.027^{*} \\
(0.056)\end{array}$ & $\begin{array}{c}-0.024 * * \\
(0.030)\end{array}$ & $\begin{array}{c}-0.026^{* * *} \\
(0.014)\end{array}$ \\
\hline Interest rate & $\begin{array}{c}-0.112 * * \\
(0.048)\end{array}$ & $\begin{array}{c}-0.112^{* *} \\
(0.047) \\
\end{array}$ & $\begin{array}{c}-0.119 * * \\
(0.041)\end{array}$ & $\begin{array}{c}-0.111^{*} \\
(0.057) \\
\end{array}$ & $\begin{array}{r}-0.117^{*} \\
(0.061) \\
\end{array}$ & $\begin{array}{c}-0.112^{* *} * \\
(0.048)\end{array}$ & $\begin{array}{c}-0.118^{* * *} \\
(0.044) \\
\end{array}$ \\
\hline ROL & & $\begin{array}{c}0.000 \\
(0.987) \\
\end{array}$ & & & & $\begin{array}{c}0.000 \\
(0.973) \\
\end{array}$ & \\
\hline KA OP & & & $\begin{array}{c}-0.001 \\
(0.806) \\
\end{array}$ & & & & \begin{tabular}{|l|}
-0.003 \\
$(0.548)$ \\
\end{tabular} \\
\hline Priv. Credit & & & & $\begin{array}{c}0.003 \\
(0.811) \\
\end{array}$ & & & \\
\hline Gov. Cons. & & & & & $\begin{array}{r}-0.258^{*} \\
(0.080) \\
\end{array}$ & & \\
\hline NEO (-1) * ROL & & & & & & $\begin{array}{c}0.004 \\
(0.918) \\
\end{array}$ & \\
\hline $\mathrm{NEO}(-1) * \mathrm{KA} \mathrm{OP}$ & & & & & & & \begin{tabular}{|c|}
$-0.326^{* * *}$ \\
$(0.012)$ \\
\end{tabular} \\
\hline Constant & $\begin{array}{l}0.154^{* * * *} \\
(0.000)\end{array}$ & $\begin{array}{l}0.154 * * * \\
(0.000)\end{array}$ & $\begin{array}{l}0.163 \text { *** } \\
(0.000)\end{array}$ & $\begin{array}{l}0.146^{* * * *} \\
(0.000)\end{array}$ & $\begin{array}{l}0.209^{* * *} \\
(0.000)\end{array}$ & $\begin{array}{l}0.154^{* * * *} \\
(0.000)\end{array}$ & $\begin{array}{l}0.166^{* * * * *} \\
(0.000)\end{array}$ \\
\hline CS fixed effects & Yes & Yes & Yes & Yes & Yes & Yes & Yes \\
\hline Time dummies & Yes & Yes & Yes & Yes & Yes & Yes & Yes \\
\hline Within $\mathrm{R}^{2}$ & 0.757 & 0.757 & 0.767 & 0.730 & 0.764 & 0.757 & 0.770 \\
\hline Between $\mathrm{R}^{2}$ & 0.907 & 0.907 & 0.915 & 0.889 & 0.874 & 0.907 & 0.911 \\
\hline Overall R2 & 0.827 & 0.827 & 0.838 & 0.809 & 0.817 & 0.827 & 0.837 \\
\hline No. of observations & 498 & 498 & 450 & 477 & 498 & 498 & 450 \\
\hline No. of countries & 35 & 35 & 31 & 35 & 35 & 35 & 31 \\
\hline Minimum periods & 8 & 8 & 11 & 8 & 8 & 8 & 11 \\
\hline Maximum periods & 15 & 15 & 15 & 15 & 15 & 15 & 15 \\
\hline CS Dep. (statistic) & -0.456 & -0.458 & -0.346 & -0.644 & -0.872 & -0.450 & -0.123 \\
\hline CS Dep. (p-value) & 0.648 & 0.647 & 0.729 & 0.520 & 0.383 & 0.653 & 0.902 \\
\hline
\end{tabular}

Note: The dependent variable is share of investment on nominal GDP, NEO stands for the share of net errors and omissions on nominal GDP, Open stands for trade openness, GDP p.c. growth stands for the overlapping annual change of logarithm of GDP p.c., Gov. Debt is share of gross general government debt on GDP, Interest rate is the lending interest rate adjusted for inflation as measured by the GDP deflator, ROL stands for the inverse of the rule of law, KA OP stands for capital account openness, Priv. Credit stands for the share of private credit on GDP, Gov. Cons. is the share of government consumption on GDP, and REER stands for real effective exchange rate growth. Time dummies for each period were included in every estimated model. Cluster robust standard errors are presented in parenthesis. Statistical significance of a parameter is indicated by following symbol "**" (* at 0.1 significance level, ** at 0.05 significance level, and $* * *$ at 0.01 level). Analogous specifications also apply for Table 3a, which reports results for capital flight estimates based on residual model (CFL RM) instead of those for NEO.

Source: Authors' estimations based on data from the World Bank and Chinn-Ito database. 
Table $2 b$

The Effect of Capital Flight (Proxied by Neo) on Total Investment: System GMM

\begin{tabular}{|c|c|c|c|c|c|c|c|}
\hline Investment & (1) & (2) & (3) & (4) & (5) & (6) & (7) \\
\hline $\operatorname{NEO}(-1)$ & $\begin{array}{r}-0.144 * \\
(0.077)\end{array}$ & $\begin{array}{r}-0.144 * \\
(0.078)\end{array}$ & $\begin{array}{c}-0.104 \\
(0.066)\end{array}$ & $\begin{array}{c}-0.108 \\
(0.069)\end{array}$ & $\begin{array}{r}-0.136^{*} \\
(0.075)\end{array}$ & $\begin{array}{r}-0.147 * \\
(0.074)\end{array}$ & $\begin{array}{c}-0.088 \\
(0.068)\end{array}$ \\
\hline Investment $(-1)$ & $\begin{array}{l}0.965^{* * * *} \\
(0.139)\end{array}$ & $\begin{array}{l}0.964 \text { *** } \\
(0.141)\end{array}$ & $\begin{array}{l}0.940^{* * * *} \\
(0.127)\end{array}$ & $\begin{array}{l}0.952 * * * \\
(0.171)\end{array}$ & $\begin{array}{c}0.956 * * * \\
(0.138)\end{array}$ & $\begin{array}{l}0.963 * * * \\
(0.142)\end{array}$ & $\begin{array}{l}0.929 * * * \\
(0.128)\end{array}$ \\
\hline Open & $\begin{array}{c}0.002 \\
(0.002)\end{array}$ & $\begin{array}{c}0.002 \\
(0.002)\end{array}$ & $\begin{array}{c}0.000 \\
(0.002)\end{array}$ & $\begin{array}{c}0.001 \\
(0.002)\end{array}$ & $\begin{array}{c}0.002 \\
(0.003)\end{array}$ & $\begin{array}{c}0.002 \\
(0.002)\end{array}$ & $\begin{array}{c}0.001 \\
(0.002)\end{array}$ \\
\hline GDP p.c. growth & $\begin{array}{l}0.408 \text { *** } \\
(0.081)\end{array}$ & $\begin{array}{l}0.410 \text { *** } \\
(0.082)\end{array}$ & $\begin{array}{l}0.411 \text { **** } \\
(0.083)\end{array}$ & $\begin{array}{l}0.374 * * * \\
(0.101)\end{array}$ & $\begin{array}{l}0.411 * * * \\
(0.093)\end{array}$ & $\begin{array}{l}0.411 \text { *** } \\
(0.082)\end{array}$ & $\begin{array}{l}0.408 * * * \\
(0.081)\end{array}$ \\
\hline Gov. Debt & $\begin{array}{c}0.011 \\
(0.012)\end{array}$ & $\begin{array}{c}0.010 \\
(0.012)\end{array}$ & $\begin{array}{c}0.009 \\
(0.011)\end{array}$ & $\begin{array}{c}0.005 \\
(0.011)\end{array}$ & $\begin{array}{c}0.010 \\
(0.011)\end{array}$ & $\begin{array}{c}0.010 \\
(0.013)\end{array}$ & $\begin{array}{c}0.008 \\
(0.011)\end{array}$ \\
\hline Interest rate & \begin{tabular}{|c|}
-0.068 \\
$(0.044)$ \\
\end{tabular} & $\begin{array}{c}-0.068 \\
(0.044)\end{array}$ & $\begin{array}{c}-0.083 \\
(0.054)\end{array}$ & $\begin{array}{c}-0.074 \\
(0.049)\end{array}$ & $\begin{array}{c}-0.067 \\
(0.047)\end{array}$ & \begin{tabular}{|c|}
-0.068 \\
$(0.044)$ \\
\end{tabular} & $\begin{array}{c}-0.084 \\
(0.054) \\
\end{array}$ \\
\hline ROL & & $\begin{array}{c}-0.001 \\
(0.001)\end{array}$ & & & & \begin{tabular}{|c|}
-0.000 \\
$(0.001)$ \\
\end{tabular} & \\
\hline KA OP & & & $\begin{array}{c}-0.005 \\
(0.004)\end{array}$ & & & & $\begin{array}{c}-0.006 \\
(0.004)\end{array}$ \\
\hline Priv. Credit & & & & $\begin{array}{c}0.004 \\
(0.010)\end{array}$ & & & \\
\hline Gov. Cons. & & & & & $\begin{array}{c}0.028 \\
(0.090)\end{array}$ & & \\
\hline $\mathrm{NEO}(-1) * \mathrm{ROL}$ & & & & & & $\begin{array}{c}0.015 \\
(0.052) \\
\end{array}$ & \\
\hline $\operatorname{NEO}(-1) *$ KA OP & & & & & & & $\begin{array}{r}-0.275^{*} \\
(0.153) \\
\end{array}$ \\
\hline Constant & $\begin{array}{c}0.031 \\
(0.041) \\
\end{array}$ & $\begin{array}{c}-0.002 \\
(0.046) \\
\end{array}$ & $\begin{array}{c}-0.045 \\
(0.040) \\
\end{array}$ & $\begin{array}{c}0.033 \\
(0.052) \\
\end{array}$ & $\begin{array}{c}-0.006 \\
(0.063) \\
\end{array}$ & \begin{tabular}{|c|}
-0.002 \\
$(0.046)$ \\
\end{tabular} & $\begin{array}{c}0.044 \\
(0.035) \\
\end{array}$ \\
\hline CS fixed effects & Yes & Yes & Yes & Yes & Yes & Yes & Yes \\
\hline Time dummies & Yes & Yes & Yes & Yes & Yes & Yes & Yes \\
\hline AR(1) (statistic) & -2.722 & -2.701 & -2.663 & -2.782 & -2.706 & -2.707 & -2.618 \\
\hline AR(1) (p-value) & 0.006 & 0.007 & 0.008 & 0.005 & 0.007 & 0.007 & 0.009 \\
\hline $\mathrm{AR}(2)$ (statistic) & -1.453 & -1.537 & -1.340 & -1.158 & -1.456 & -1.524 & -1.368 \\
\hline $\mathrm{AR}(2)$ (p-value) & 0.146 & 0.124 & 0.180 & 0.247 & 0.145 & 0.127 & 0.171 \\
\hline Sargan test (statistic) & 0.633 & 0.683 & 0.000 & 0.897 & 0.651 & 0.684 & 0.001 \\
\hline Sargan test (p-value) & 0.426 & 0.408 & 0.989 & 0.344 & 0.420 & 0.408 & 0.980 \\
\hline Hansen J (statistic) & 0.540 & 0.586 & 0.000 & 0.776 & 0.573 & 0.574 & 0.001 \\
\hline Hansen J (p-value) & 0.462 & 0.444 & 0.988 & 0.378 & 0.449 & 0.449 & 0.979 \\
\hline CS Dep. (statistic) & 0.529 & 0.547 & 0.521 & 0.736 & 0.634 & 0.569 & 0.651 \\
\hline CS Dep. (p-value) & 0.596 & 0.584 & 0.602 & 0.461 & 0.526 & 0.569 & 0.515 \\
\hline No. of observations & 498 & 498 & 450 & 477 & 498 & 498 & 450 \\
\hline No. of countries & 35 & 35 & 31 & 35 & 35 & 35 & 31 \\
\hline Minimum periods & 8 & 8 & 11 & 8 & 8 & 8 & 11 \\
\hline Maximum periods & 15 & 15 & 15 & 15 & 15 & 15 & 15 \\
\hline Number of instrument & 22 & 23 & 23 & 23 & 23 & 24 & 24 \\
\hline
\end{tabular}

Note: The dependent variable is share of investment on nominal GDP, NEO stands for the share of net errors and omissions on nominal GDP, Open stands for trade openness, GDP p.c. growth stands for the overlapping annual change of logarithm of GDP p.c., Gov. Debt is share of gross general government debt on GDP, Interest rate is the lending interest rate adjusted for inflation as measured by the GDP deflator, ROL stands for the inverse of the rule of law, KA OP stands for capital account openness, Priv. Credit stands for the share of private credit on GDP, Gov. Cons. is the share of government consumption on GDP, and REER stands for real effective exchange rate growth. Time dummies were included in every estimated model. Windmeijer's finite-sample correction was performed on standard errors, which are presented in parenthesis. Statistical significance of a parameter is indicated by following symbol "*" (* at 0.1 significance level, ** at 0.05 significance level, and *** at 0.01 level). Following, the results of first and second order autocorrelation tests (AR) are provided, together with results of Sargan's over-identifying restrictions test and Hansen $\mathbf{J}$ statistic. Analogous specifications also apply for Table $3 \mathrm{~b}$, which reports results for capital flight estimates based on residual model (CFL RM) instead of those for NEO.

Source: Authors' estimations based on data from the World Bank and Chinn-Ito database. 
For the robustness check, we also employed system general method of moments (GMM) estimators (Table 2b). While the coefficient on the lag of capital flight remains stable as in OLS, two things change. First, the autoregressive terms now yield higher marginal effects. Two, with the exception of GDP per capita growth, which remains stable, other variables turn out to be statistically insignificant, albeit still with the expected signs. Overall, the results are in line with our results in the OLS regression and previous findings (Fofack and Ndikumana, 2009; Yalta, 2010).

Table $3 a$

The Effect of Capital Flight (Proxied by Residual Model Estimate) on Total Investment: FE OLS

\begin{tabular}{|c|c|c|c|c|c|c|c|}
\hline Investment & (1) & (2) & (3) & (4) & (5) & (6) & (7) \\
\hline CFL RM (-1) & $\begin{array}{c}-0.008 * \\
(0.063)\end{array}$ & $\begin{array}{c}-0.008 * \\
(0.061)\end{array}$ & $\begin{array}{c}-0.010 \\
(0.396)\end{array}$ & $\begin{array}{c}-0.007 \\
(0.109)\end{array}$ & $\begin{array}{c}-0.009 * \\
(0.066)\end{array}$ & $\begin{array}{c}-0.008 * \\
(0.059)\end{array}$ & $\begin{array}{c}-0.010 \\
(0.390) \\
\end{array}$ \\
\hline Investment $(-1)$ & $\begin{array}{l}0.699 * * * \\
(0.000)\end{array}$ & $\begin{array}{l}0.695^{* * * *} \\
(0.000)\end{array}$ & $\begin{array}{l}0.689 \text { *** } \\
(0.000)\end{array}$ & $\begin{array}{l}0.688 * * * \\
(0.000)\end{array}$ & $\begin{array}{l}0.685^{* * *} * \\
(0.000)\end{array}$ & $\begin{array}{l}0.697^{* * *} * \\
(0.000)\end{array}$ & $\begin{array}{l}0.687 * * * \\
(0.000)\end{array}$ \\
\hline Open & $\begin{array}{c}-0.002 \\
(0.890) \\
\end{array}$ & $\begin{array}{c}-0.002 \\
(0.892)\end{array}$ & $\begin{array}{c}-0.016 \\
(0.606)\end{array}$ & $\begin{array}{c}-0.001 \\
(0.962)\end{array}$ & $\begin{array}{c}-0.002 \\
(0.898)\end{array}$ & $\begin{array}{c}-0.002 \\
(0.912)\end{array}$ & $\begin{array}{c}-0.017 \\
(0.583)\end{array}$ \\
\hline GDP p.c. growth & $\begin{array}{l}0.425^{* * * *} \\
(0.000)\end{array}$ & $\begin{array}{l}0.421 * * * \\
(0.000)\end{array}$ & $\begin{array}{l}0.454 * * * \\
(0.000)\end{array}$ & $\begin{array}{l}0.384 * * * \\
(0.000)\end{array}$ & $\begin{array}{l}0.415^{* * *} * \\
(0.000)\end{array}$ & $\begin{array}{l}0.421^{* * *} \\
(0.000)\end{array}$ & $\begin{array}{l}0.455^{* * *} \\
(0.000) \\
\end{array}$ \\
\hline Gov. Debt & $\begin{array}{c}-0.028 * * * \\
(0.009)\end{array}$ & $\begin{array}{c}-0.029 * * * \\
(0.008)\end{array}$ & $\begin{array}{c}-0.028 * * \\
(0.013)\end{array}$ & $\begin{array}{c}-0.030 * * * \\
(0.007)\end{array}$ & $\begin{array}{r}-0.031 * \\
(0.053)\end{array}$ & $\begin{array}{c}-0.029 * * * \\
(0.009)\end{array}$ & $\begin{array}{c}-0.027 * * \\
(0.019)\end{array}$ \\
\hline Interest rate & $\begin{array}{r}-0.116^{*} \\
(0.097)\end{array}$ & $\begin{array}{r}-0.115 * \\
(0.096)\end{array}$ & $\begin{array}{r}-0.128 * \\
(0.066)\end{array}$ & $\begin{array}{c}-0.114 \\
(0.108)\end{array}$ & $\begin{array}{c}-0.109 \\
(0.151)\end{array}$ & $\begin{array}{r}-0.114 * \\
(0.099)\end{array}$ & $\begin{array}{r}-0.129 * \\
(0.066)\end{array}$ \\
\hline ROL & & $\begin{array}{c}0.000 \\
(0.454)\end{array}$ & & & & $\begin{array}{c}0.000 \\
(0.542) \\
\end{array}$ & \\
\hline KA OP & & & $\begin{array}{c}-0.003 \\
(0.736) \\
\end{array}$ & & & & $\begin{array}{c}-0.004 \\
(0.604) \\
\end{array}$ \\
\hline Priv. Credit & & & & $\begin{array}{c}0.003 \\
(0.832) \\
\end{array}$ & & & \\
\hline Gov. Cons. & & & & & $\begin{array}{c}-0.244 \\
(0.255)\end{array}$ & & \\
\hline CFL RM (-1) * ROL & & & & & & $\begin{array}{c}0.002 \\
(0.558)\end{array}$ & \\
\hline CFL RM $(-1) *$ KA OP & & & & & & & $\begin{array}{c}-0.055 \\
(0.377) \\
\end{array}$ \\
\hline Constant & $\begin{array}{l}0.118^{* * *} * \\
(0.000)\end{array}$ & $\begin{array}{l}0.119 \text { *** } \\
(0.000)\end{array}$ & $\begin{array}{l}0.136^{* * * *} \\
(0.000)\end{array}$ & $\begin{array}{l}0.116^{* * * *} \\
(0.000)\end{array}$ & $\begin{array}{l}0.170 * * \\
(0.017)\end{array}$ & $\begin{array}{l}0.118^{* * *} * \\
(0.000)\end{array}$ & $\begin{array}{l}0.137^{* * *} * \\
(0.000)\end{array}$ \\
\hline CS fixed effects & Yes & Yes & Yes & Yes & Yes & Yes & Yes \\
\hline Time dummies & Yes & Yes & Yes & Yes & Yes & Yes & Yes \\
\hline Within $\mathrm{R}^{2}$ & 0.806 & 0.806 & 0.817 & 0.774 & 0.810 & 0.806 & 0.818 \\
\hline Between $\mathrm{R}^{2}$ & 0.911 & 0.910 & 0.882 & 0.903 & 0.871 & 0.910 & 0.878 \\
\hline Overall R2 & 0.859 & 0.858 & 0.855 & 0.847 & 0.836 & 0.858 & 0.854 \\
\hline No. of observations & 390 & 390 & 368 & 379 & 390 & 390 & 368 \\
\hline No. of countries & 31 & 31 & 29 & 31 & 31 & 31 & 29 \\
\hline Minimum periods & 4 & 4 & 4 & 4 & 4 & 4 & 4 \\
\hline Maximum periods & 14 & 14 & 14 & 14 & 14 & 14 & 14 \\
\hline CS Dep. (statistic) & -0.868 & -0.934 & -0.624 & -0.591 & -1.252 & -0.953 & -0.650 \\
\hline CS Dep. (p-value) & 0.386 & 0.350 & 0.532 & 0.554 & 0.210 & 0.341 & 0.515 \\
\hline
\end{tabular}

Note: See note for Table 2a.

Source: Authors' estimations based on data from the World Bank and Chinn-Ito database. 
T a b le $3 b$

The Effect of Capital Flight (Proxied by Residual Model Estimate) on Total Investment: System GMM

\begin{tabular}{|c|c|c|c|c|c|c|c|}
\hline Investment & (1) & (2) & (3) & (4) & (5) & (6) & (7) \\
\hline CFL RM $(-1)$ & $\begin{array}{l}-0.012^{* * * *} \\
(0.004)\end{array}$ & $\begin{array}{c}-0.014 * * * \\
(0.004)\end{array}$ & $\begin{array}{c}-0.021 \\
(0.012)\end{array}$ & $\begin{array}{c}-0.012 * * * \\
(0.004)\end{array}$ & $\begin{array}{c}-0.012 * * * \\
(0.004)\end{array}$ & $\begin{array}{c}-0.014 * * * \\
(0.004)\end{array}$ & $\begin{array}{r}-0.024 * \\
(0.013)\end{array}$ \\
\hline Investment $(-1)$ & $\begin{array}{l}0.632 * * * \\
(0.114)\end{array}$ & $\begin{array}{l}0.620 * * * \\
(0.105)\end{array}$ & $\begin{array}{l}0.537 \text { *** } \\
(0.113)\end{array}$ & $\begin{array}{l}0.636 * * * \\
(0.041)\end{array}$ & $\begin{array}{l}0.612 \text { *** } \\
(0.117)\end{array}$ & $\begin{array}{l}0.638 * * * \\
(0.114)\end{array}$ & $\begin{array}{l}0.511 \text { *** } \\
(0.115)\end{array}$ \\
\hline Open & $\begin{array}{c}-0.003 \\
(0.003)\end{array}$ & $\begin{array}{c}-0.002 \\
(0.004)\end{array}$ & $\begin{array}{c}0.003 \\
(0.007)\end{array}$ & $\begin{array}{c}-0.002 \\
(0.003)\end{array}$ & $\begin{array}{c}-0.003 \\
(0.004)\end{array}$ & $\begin{array}{c}-0.002 \\
(0.004)\end{array}$ & $\begin{array}{c}0.004 \\
(0.006)\end{array}$ \\
\hline GDP p.c. growth & $\begin{array}{l}0.439 * * * \\
(0.057)\end{array}$ & $\begin{array}{l}0.446^{* * * *} \\
(0.062) \\
\end{array}$ & $\begin{array}{l}0.436^{* * * *} \\
(0.070)\end{array}$ & $\begin{array}{l}0.388 * * * \\
(0.052) \\
\end{array}$ & $\begin{array}{l}0.446^{* * * *} \\
(0.060)\end{array}$ & $\begin{array}{l}0.446^{* * * *} \\
(0.060) \\
\end{array}$ & $\begin{array}{l}0.438 * * * \\
(0.063) \\
\end{array}$ \\
\hline Gov. Debt & $\begin{array}{c}-0.014 \\
(0.010)\end{array}$ & $\begin{array}{c}-0.013 \\
(0.009)\end{array}$ & $\begin{array}{c}-0.014 \\
(0.010)\end{array}$ & $\begin{array}{c}-0.012 * \\
(0.006)\end{array}$ & $\begin{array}{c}-0.015 \\
(0.011)\end{array}$ & $\begin{array}{c}-0.011 \\
(0.010)\end{array}$ & $\begin{array}{c}-0.014 \\
(0.010)\end{array}$ \\
\hline Interest rate & $\begin{array}{c}-0.100 * * \\
(0.046) \\
\end{array}$ & $\begin{array}{c}-0.101^{* *} \\
(0.042)\end{array}$ & $\begin{array}{c}-0.123^{* *} \\
(0.053) \\
\end{array}$ & $\begin{array}{c}-0.108 * * \\
(0.050)\end{array}$ & $\begin{array}{c}-0.105^{* *} \\
(0.045)\end{array}$ & $\begin{array}{c}-0.100 * * \\
(0.041)\end{array}$ & $\begin{array}{c}-0.117^{* *} \\
(0.049)\end{array}$ \\
\hline ROL & & $\begin{array}{c}0.001 * \\
(0.000)\end{array}$ & & & & $\begin{array}{c}0.001 * \\
(0.000)\end{array}$ & \\
\hline KA OP & & & $\begin{array}{c}0.004 \\
(0.010)\end{array}$ & & & & $\begin{array}{c}0.003 \\
(0.008)\end{array}$ \\
\hline Priv. Credit & & & & $\begin{array}{c}-0.003 \\
(0.006)\end{array}$ & & & \\
\hline Gov. Cons. & & & & & $\begin{array}{c}-0.010 \\
(0.068) \\
\end{array}$ & & \\
\hline CFL RM $(-1) *$ ROL & & & & & & $\begin{array}{c}0.003 \\
(0.003) \\
\end{array}$ & \\
\hline CFL RM $(-1) *$ KA OP & & & & & & & $\begin{array}{c}-0.084 \\
(0.056)\end{array}$ \\
\hline Constant & $\begin{array}{l}0.086^{* *} * \\
(0.031)\end{array}$ & $\begin{array}{l}0.087 * * * \\
(0.029)\end{array}$ & $\begin{array}{l}0.090 * * * \\
(0.031)\end{array}$ & $\begin{array}{c}0.017 \\
(0.019)\end{array}$ & $\begin{array}{l}0.147 * * * \\
(0.045)\end{array}$ & $\begin{array}{l}0.080 * * \\
(0.032)\end{array}$ & $\begin{array}{c}0.029 \\
(0.031)\end{array}$ \\
\hline CS fixed effects & Yes & Yes & Yes & Yes & Yes & Yes & Yes \\
\hline Time dummies & Yes & Yes & Yes & Yes & Yes & Yes & Yes \\
\hline AR(1) (statistic) & -2.374 & -2.475 & -2.202 & -2.565 & -2.316 & -2.442 & -2.060 \\
\hline $\mathrm{AR}(1)(\mathrm{p}$-value) & 0.018 & 0.013 & 0.028 & 0.010 & 0.021 & 0.015 & 0.039 \\
\hline $\operatorname{AR}(2)$ (statistic) & -1.494 & -1.410 & -1.438 & -1.305 & -1.476 & -1.424 & -1.543 \\
\hline $\operatorname{AR}(2)(p-v a l u e)$ & 0.135 & 0.159 & 0.151 & 0.192 & 0.140 & 0.154 & 0.123 \\
\hline Sargan test (statistic) & 19.433 & 19.641 & 23.590 & 19.844 & 19.517 & 19.261 & 22.560 \\
\hline Sargan test (p-value) & 0.195 & 0.186 & 0.072 & 0.178 & 0.191 & 0.202 & 0.094 \\
\hline Hansen J (statistic) & 10.202 & 8.654 & 6.494 & 7.640 & 9.276 & 8.168 & 5.659 \\
\hline Hansen J (p-value) & 0.807 & 0.895 & 0.970 & 0.937 & 0.863 & 0.917 & 0.985 \\
\hline CS Dep. (statistic) & -1.047 & -0.790 & -0.168 & -0.770 & -0.852 & -0.627 & -0.518 \\
\hline CS Dep. (p-value) & 0.295 & 0.430 & 0.867 & 0.441 & 0.394 & 0.530 & 0.604 \\
\hline No. of observations & 390 & 390 & 368 & 379 & 390 & 390 & 368 \\
\hline No. of countries & 31 & 31 & 29 & 31 & 31 & 31 & 29 \\
\hline Minimum periods & 4 & 4 & 4 & 4 & 4 & 4 & 4 \\
\hline Maximum periods & 14 & 14 & 14 & 14 & 14 & 14 & 14 \\
\hline Number of instrument & 35 & 36 & 36 & 36 & 36 & 37 & 37 \\
\hline
\end{tabular}

Note: See note for Table $2 \mathrm{~b}$.

Source: Authors' estimations based on data from the World Bank and Chinn-Ito database.

Table (3a) presents our estimates based on the residual model and OLS. The results suggest that the marginal effect of lag of capital flight, though smaller in scale, remains statistically significant in most of the specifications, except when 
financial liberalization (KAOP) and private credit are included as control variables. The other control variables remain similar to our first specification using net errors and omissions as a proxy for capital flight (Table 2a). Turning to our GMM regressions (Table $3 b$ ) for robustness checks, the results remain fairly stable, and most of the control variables (except policy-related ones) are statistically significant. The marginal effect of capital flight increases slightly from 0.008 in Table 3 to 0.011 in Table 4 . This outcome implies that an increase in capital flight by $1 \%$ of GDP may lead to a decrease in domestic investment by 0.008 to $0.011 \%$ of GDP. Our findings are surprisingly similar to those for emerging economies (Yalta, 2010).

T a ble 4

List of All Included Countries in the Sample Used

\begin{tabular}{|c|c|c|}
\hline CountrylNo. of Years Used & Max & Min \\
\hline Albania & 15 & 10 \\
\hline Austria & 12 & 12 \\
\hline Belarus & 14 & 14 \\
\hline Belgium & 15 & 13 \\
\hline Bosnia and Herzegovina & 15 & 0 \\
\hline Bulgaria & 15 & 11 \\
\hline Croatia & 12 & 11 \\
\hline Czech Republic & 15 & 14 \\
\hline Denmark & 15 & 13 \\
\hline Estonia & 15 & 14 \\
\hline Finland & 15 & 14 \\
\hline France & 15 & 14 \\
\hline Georgia & 15 & 9 \\
\hline Germany & 15 & 14 \\
\hline Greece & 15 & 13 \\
\hline Hungary & 15 & 14 \\
\hline Ireland & 12 & 0 \\
\hline Italy & 15 & 14 \\
\hline Latvia & 15 & 13 \\
\hline Lithuania & 15 & 13 \\
\hline Luxembourg & 15 & 0 \\
\hline Malta & 11 & 4 \\
\hline Moldova & 14 & 11 \\
\hline Montenegro & 10 & 0 \\
\hline Netherlands & 15 & 13 \\
\hline Poland & 15 & 14 \\
\hline Portugal & 15 & 14 \\
\hline Romania & 15 & 0 \\
\hline Serbia & 8 & 0 \\
\hline Slovak Republic & 15 & 13 \\
\hline Slovenia & 15 & 14 \\
\hline Spain & 15 & 14 \\
\hline Sweden & 15 & 14 \\
\hline Ukraine & 15 & 13 \\
\hline United Kingdom & 15 & 14 \\
\hline Total & 498 & 368 \\
\hline
\end{tabular}

Source: Authors' estimations based on data from the World Bank and Chinn-Ito database. 
Figure 1

\section{NEO (\% of GDP)}
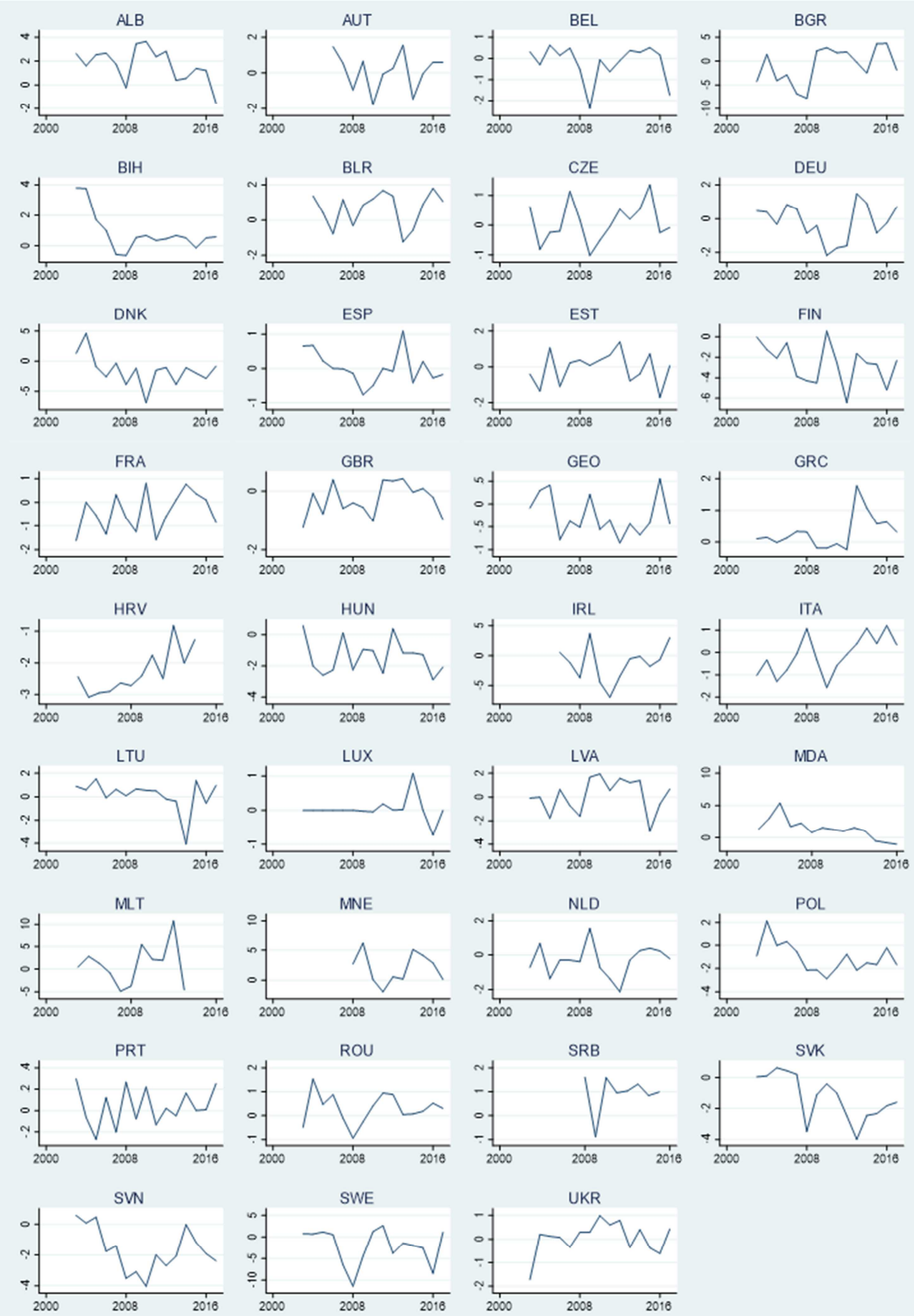

Source: Authors' estimations based on data from the World Bank and Chinn-Ito database. 
Figure 2

\section{Residual Model (\% of GDP)}
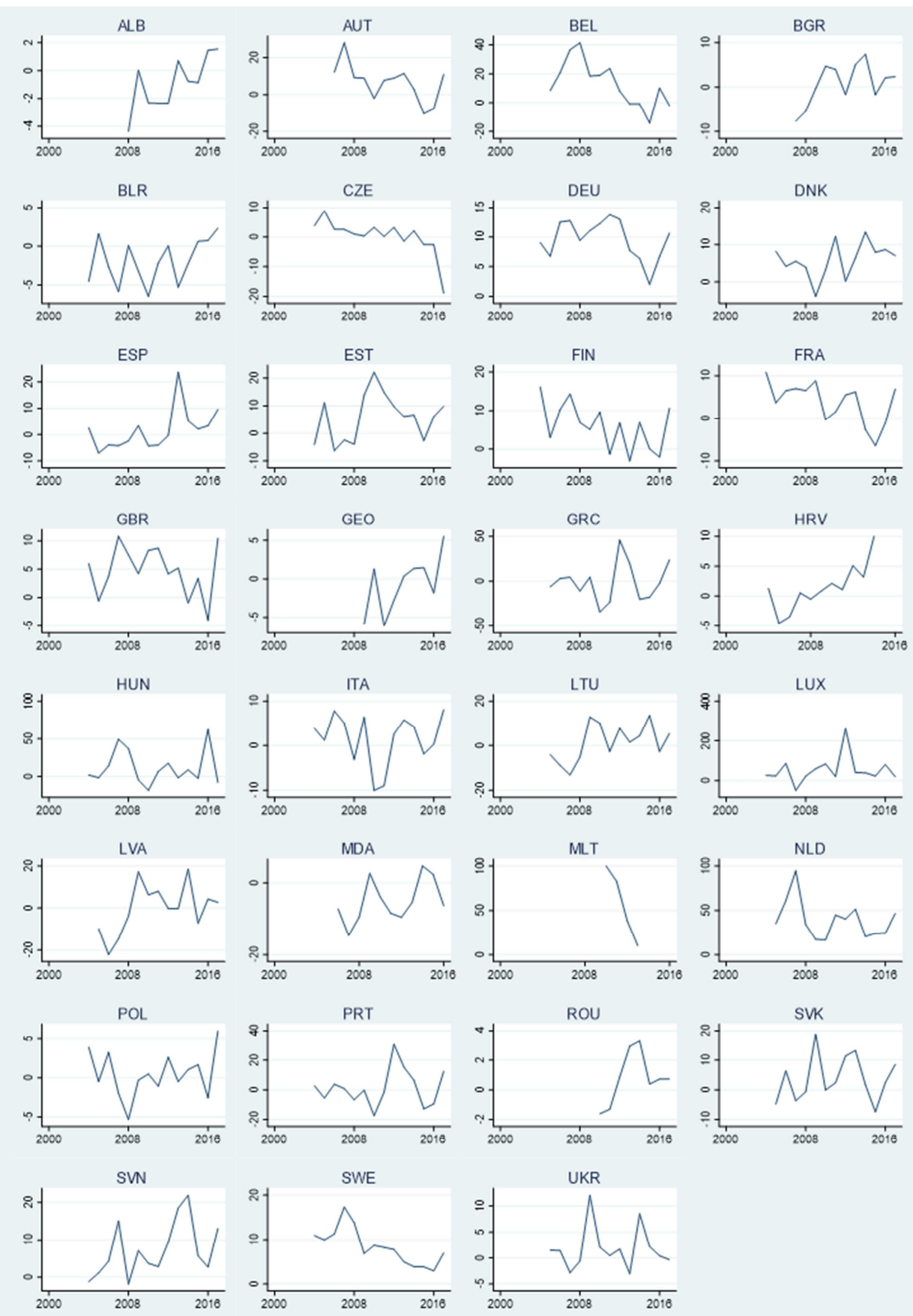

Source: Authors' estimations based on data from the World Bank and Chinn-Ito database. 


\section{Conclusions}

In a world that is increasingly interconnected both in trade and capital flows, capital flight has become and will probably continue to be a significant challenge to policy makers. While the magnitude and impact of capital flight is more pronounced in developing economies because of the notorious issue of high capital scarcity in these countries, other emerging and advanced economies do not seem to be immune to the phenomenon of unrecorded financial flows. Despite how vague this concept still is, there is nonetheless a recognition that capital flight has become a worldwide problem, with numerous studies and documents (the Panama Papers and the Paradise Papers) signaling firms' and individuals' attempts to hide their wealth from tax authorities. As most previous studies have argued, what is referred to as "tax optimization" could be conceptually legal but morally illegitimate, as it occurs at the expense of the social rate of return, declining domestic investment and an overall sluggish economic performance.

While numerous previous results have focused mainly on the drivers of capital flight, only a few have investigated the ramifications of such unrecorded capital flows for domestic investment and growth. Our results based on the advanced and emerging parts of Europe for which data are available seem to suggest the prevalence of capital flight and other forms of illicit financial flows, despite the presence of cross-country variation. Our findings based on two proxies for capital flight (net errors and omissions and the residual model) and panel OLS and system GMM seem to suggest capital flight occurs at the expense of domestic investment. The results also suggest that except for a single case (ROL in Table 3b) in which policy matters, the impact of capital flight on domestic investment is fairly stable and significant in a statistical sense.

This finding calls for policy shifts in the direction of cooperation among financial institutions responsible for recording transactions as well as governments in terms of coordinating their policies to reduce the scale of capital flight.

\section{References}

AJAYI, S. I. (1997): An Analysis of External Debt and Capital Flight in the Severely Indebted Low Income Countries in Sub-Saharan Africa. [IMF Working Papers 97/68.] Washington, DC: International Monetary Fund.

ANTZOULATOS, A. A. - SAMPANIOTIS, T. (2002): Capital Flight in the 1990s - Lessons from Eastern Europe. [Working Paper presented at the $51^{\text {st }}$ International Atlantic Economic Conference in Athens, Greece.]

AYADI, F. S. (2008a): Econometric Analysis of Capital Flight in Developing Countries. $8^{\text {th }}$ Global Conference \& Economics in Florence, Italy.] ISBN 978-0-9742114-5-9.

BAKER, R. (2005): Capitalism's Achilles Heel: Dirty Money and How to Renew the Free Market System. Hoboken, NJ: J. Wiley \& Sons. 
BARRO, R. J. (1974): Are Government Bonds Net Wealth? Journal of Political Economy, 82, No. 6, pp. $1095-1117$.

BLANKENBURG, S. - KHAN, M. (2012): Governance and Illicit Flows. In: REUTER, P. (ed.): Draining Development? Controlling Flows of Illicit Funds from Developing Countries. Washington, DC: The World Bank, pp. $21-68$.

BOYCE, J. K. - NDIKUMANA, L. (2001): Is Africa a Net Creditor? New Estimates of Capital Flight from Severely Indebted Sub-Saharan African Countries, 1970 - 1996. Journal of Development Studies, 38, No. 2, pp. $27-56$.

BRADA, J. C. - KUTAN, A. M. - VUKŠIĆ, G. (2011): The Costs of Moving Money across Borders and the Volume of Capital Flight: The Case of Russia and other CIS Countries. Review of World Economics, 147, No. 4, pp. $717-744$.

BRADA, J. C. - KUTAN, A. M. - VUKŠIĆ, G. (2013): Capital Flight in the Presence of Domestic Borrowing: Evidence from Eastern European Economies. World Development, 51, No. C, pp. 32 - 46. Available at: 〈http://dx.doi.org/10.1016/j.worlddev.2013.05.007〉.

BUITER, W. H. - SZEGVARI, I. (2002): Capital Flight and Capital Outflows from Russia: Symptom, Cause and Cure. [Working Paper, No. 73.] London: EBRD.

CERRA, V. - RISHI, M. - SAXENA, S. C. (2005): Robbing the Riches: Capital Flight, Institutions, and Instability. [IMF Working Paper, No. 05/199, October 2005.] Washington, DC: International Monetary Fund.

CHECHERITA-WESTPHAL, C. - ROTHER, P. (2012): The Impact of High Government Debt on Economic Growth and Its Channels: An Empirical Investigation for the Euro Area. European Economic Review, 56, No. 7, pp. 1392 - 1405.

CHEUNG, Y. W. - QIAN, X. W. (2010): Capital Flight: China's Experience. Review of Development Economics, 14, No. 2, pp. $227-247$.

CHIPALKATTI, N. - RISHI, M. (2013): External Debt and Capital Flight in the Indian Economy. Oxford Development Studies, 29, No. 1, pp. $31-44$.

CHUDIK, A. - PESARAN, M. H. (2015): Large Panel Data Models with Cross-Sectional Dependence a Survey. In: BALTAGI, B. H. (ed.): Oxford Handbook of Panel Data. New York: Oxford University Press, pp. 3 - 45.

COBHAM, A. - JANSKÝ, P. (2017): Global Distribution of Revenue Loss from Tax Avoidance: Re-estimation and Country Results. [WIDER Working Paper 55/2017.] Helsinki: UNUWIDER.

COLliER, P. - HOEFFlER, A. - PATTILlO, C. (2001): Flight Capital as a Portfolio Choice. World Bank Economic Review, 15, No. 1, pp. 55 - 79.

CUDDINGTON, J. T. (1986): Capital Flight: Estimates, Issues, and Explanations. Princeton Studies in International Finance, No. 58, pp. 1 - 44.

DITZEN, J. (2016): XTCD2: Stata Module to Test for Weak Cross Sectional Dependence. [Statistical Software Components S458204a.] Boston: Boston College Department of Economics, revised 15 Jul 2019.

DOOLEY, M. P. - KLETZER, K. M. (1994): Capital Flight, External Debt, and Domestic Policies. [NBER Working Papers 4793.] Cambridge, MA: National Bureau of Economic Research.

DORNBUSCH, R. (1987): Exchange Rate Economics. The Economic Journal, 97, No. 385, pp. 1 - 18.

EATON, J. (1987): Public Debt Guarantees and Private Capital Flight. World Bank Economic Review, 1, No. 3, pp. $377-395$.

EDWARDS, S. (2001): Capital Mobility and Economic Performance: Are Emerging Economies Different? [NBER Working Paper, No. 8076.] Cambridge, MA: National Bureau of Economic Research.

EDWARDS, S. (1989): Capital Flows and the Emerging Economies: Theory, Evidence, and Controversies. Chicago: University of Chicago Press.

EPSTEIN, G. (2005): Capital Flight and Capital Controls in Developing Countries. Northampton: Edward Elgar Press.

FEDDERKE, J. - LIU, W. (2002): Modelling the Determinants of Capital Flows and Capital Flight: With an Application to South African Data from 1960 to 1995. Economic Modelling, 19, No. 3, pp. $419-444$. 
FIDRMUC, J. - HAKE, M. - STIX, H. (2013): Households' Foreign Currency Borrowing in Central and Eastern Europe. Journal of Banking \& Finance, 37, No. 6, pp. 1880 - 1897.

FOFACK, H. - NDIKUMANA, L. (2009): Potential Gains from Capital Flight Repatriation for Sub-Saharan African Countries. [Policy Research Working Paper Series 5024.] Washington, DC: The World Bank.

FOFACK, H. - NDIKUMANA, L. (2010): Capital Flight Repatriation: Investigation of its Potential Gains for Sub-Saharan African Countries. African Development Review, 22, No. 1, pp. 4 - 22.

FORGHA, N. G. (2008): Capital Flight, Measurability and Economic Growth in Cameroon: An Econometric Investigation. International Review of Business Research Papers, 4, No. 2, pp. 74 - 90.

GLOBAL FINANCIAL INTEGRITY (2017): Illicit Financial Flows to and from Developing Countries: 2005 - 2014. Washington, DC: Global Financial Integrity.

GREENE, J. E. (2002): The Output Decline in Asian Crisis Countries: Investment Aspects. [Working Paper, WP/02/25.] Washington, DC: International Monetary Fund.

GUNTER, F. R. (2008): Capital Flight. In: DARITY, W. A. Jr. (ed.): International Encyclopedia of the Social Sciences. $2^{\text {nd }}$ ed. Detroit: Macmillan Reference, pp. $434-436$.

HAN, Y. - GAN, C. - HU, B. - LI, Z. (2012): Hong Kong Capital Flight: Determinants and Features. Investment Management and Financial Innovations, 9, No. 3, pp. 33 - 46.

HERMES, N. - LENSINK, R. (2001): Capital Flight and the Uncertainty of Government Policies. Economics Letters, 71, No. 3, pp. $377-381$.

HERMES, N. - LENSINK, R. (2014): Financial Liberalization and Capital Flight: Evidence from the African Continent. [SOM Research Reports; Vol. 14031-EEF.] Groningen: University of Groningen, SOM Research School.

HERMES, N. - LENSINK, R. - MURINDE, V. (2002): Flight Capital and its Reversal for Development Financing. [WIDER Working Paper Series 099.] Helsinki: World Institute for Development Economic Research (UNU-WIDER).

JANSKÝ, P. - PALANSKY, M. (2017): Estimating the Scale of Profit Shifting and Tax Revenue Losses Related to Foreign Direct Investment. [IES Working Paper, 25/2017.] Prague: Institute of Economic Studies, Faculty of Social Sciences Charles University in Prague.

KANT, C. (1996): Foreign Direct Investment and Capital Flight. Princeton Studies in International Finance, 80 , pp. $1-38$.

KANITZ, S. (1984): Renegotiating the Brazilian Debt. The Wall Street Journal, Sept. 21, p. 45.

LANE, P. R. - MILESI-FERRETTI, G. M. (2007): The External Wealth of Nations Mark II: Revised and Extended Estimates of Foreign Assets and Liabilities, 1970 - 2004. Journal of International Economics, 73, No. 2, pp. 223 - 250.

LENSINK, R. - HERMES, N. - MURINDE, V. (2002): Capital Flight and Political Risk. Journal of International Money and Finance, 19, No. 1, pp. 73 - 92.

LESSARD, D. - WILLIAMSON, J. (1987): Capital Flight and the Third World Debt. Washington, DC: Institute of International Economics.

LE, Q. - RISHI, M. (2006): Corruption and Capital Flight: An Empirical Assessment. International Economic Journal, Taylor \& Francis Journals, 20, No. 4, pp. 523 - 540.

LE, V. Q - ZAL, P. J. (2006): Political Risk and Capital Flight. Journal of International Money and Finance, 25, No. 2, pp. $308-329$.

LEVINE, R. - RENELT, D. (1992): A Sensitivity Analysis of Cross-Country Growth Regressions. American Economic Review, 82, No. 4, pp. 942 - 963.

LOUNGANI, P. - MAURO, P. (2000): Capital Flight from Russia. [IMF Policy Discussion Papers, No. 00/6.] Washington, DC: International Monetary Fund.

LUCAS, R. E. Jr. (1990): Why Doesn't Capital Flow from Rich to Poor Countries? The American Economic Review, 80, No. 2, pp. $92-96$.

MANKIW, N. G. - ROMER, D. - WEIL, D. N. (1992): A Contribution to the Empirics of Economic Growth. Quarterly Journal of Economics, 107, May, pp. 407 - 437.

NDIAYE, A. S. (2009): Capital Flight from the Franc Zone: Exploring the Impact on Economic Growth. [AERC Research Paper 269.] Nairobi: African Economic Research Consortium. 
NDIKUMANA, L. - BOYCE, J. K. (2011): Capital Flight from Sub-Saharan Africa: Linkages with External Borrowing and Policy Options. International Review of Applied Economics, 25, No. 2, pp. $149-170$.

NDIKUMANA, L. - BOYCE, J. K. (2018): Capital Flight from Africa: Updated Methodology and Estimates. [PERI Working Paper, June 2018.] Amherst, MA: Peri.

NDIKUMANA, L. - SARR, M. (2019): Capital Flight, Foreign Direct Investment and Natural Resources in Africa. [Working Paper, No. 2019-12.] Amherst, MA: University of Massachusetts, Department of Economics.

NDIKUMANA, L. - BOYCE, J. K. - NDIAYE, A. S. (2014): Capital Flight: Measurement and Drivers. In: AJAYI, S. I. and NDIKUMANA, L. (eds): Capital Flight from Africa: Causes, Effects and Policy Issues. Oxford: Oxford University Press.

PASTOR, M. (1990): Capital Flight and the Latin American Debt Crisis. Washington, DC: Economic Policy Institute.

PATTILlO, C. A. - POIRSON WARD, H. - RICCI, L. A. (2002): External Debt and Growth. [IMF Working Paper, No. 02/69.] Washington, DC: International Monetary Fund. Available at: <https://ssrn.com/abstract=879569>.

PEREZ, M. F. - BRADA, J. C. - DRABEK, Z. (2012): Illicit Money Flows as Motives for FDI. Journal of Comparative Economics, 40, No. 1, pp. 108 - 126.

QUAN, L. - RISHI, M. (2006): Corruption and Capital Flight: An Empirical Assessment. International Economic Journal, 20, No. 4, pp. 523 - 540.

ROODMAN, D. (2009): How to do xtabond2: An Introduction to Difference and System GMM in Stata. The Stata Journal, 9, No. 1, pp. 86 - 136. Available at: <https://doi.org/10.1177/1536867X0900900106>.

SACHS, J. (1986): Managing the LDC Debt Crisis. Brookings Papers on Economic Activity, 2, No. 2, pp. $197-431$.

SCHNEIDER, B. (2003): Measuring Capital Flight: Estimates and Interpretations. [Working Papers, No. 194.] London: Overseas Development Institute.

SIRANOVA, M. - WORKIE TIRUNEH, M. (2017): Exploding net Errors and Omissions as a Capital Flight Phenomenon: The Case of Slovakia. Applied Economics, 50, No. 16, pp. 1866 $-1884$.

SOLOW, R. M. (1956): A Contribution to the Theory of Economic Growth. The Quarterly Journal of Economics, 70, No. 1, pp. $65-94$.

TIKHOMIROV, V. (1997): Capital Flight from Post-Soviet Russia. Europe-Asia Studies, 49, No. 4, pp. $591-615$.

TORNELL, A. - VELASCO, A. (1992): The Tragedy of the Commons and Economic Growth: Why Does Capital Flow from Poor to Rich Countries? Journal of Political Economy, 100, No. 6, pp. $1208-1231$.

VARMAN-SCHNEIDER, S. (1991): Capital Flight from Developing Countries. Boulder: Westview Press.

WORLD BANK (1985): World Development Report 1985. Washington, DC: The World Bank.

WORLD BANK (2019): Worldwide Governance Indicators. Washington, DC: The World Bank. Available at: <https://databank.worldbank.org/world-bank-data-rule-of-law/id/c92bd494>.

WORLD CUSTOM ORGANIZATION (2019): Annual Reports. Available at: <http://www.wcoomd.org/en/about-us/what-is-the-wco/annual-reports.aspx>.

YALTA, A. Y. (2010): Effect of Capital Flight on Investment: Evidence from Emerging Markets. Emerging Markets Finance and Trade, 46, No. 6, pp. $40-54$.

YALTA, A. Y. - YALTA, A. T. (2012): Does financial Liberalization Decrease Capital Fight? A Panel Causality Analysis. International Review of Economics \& Finance, 22, No. 1, pp. 92 - 100.

ZUCMAN, G. (2013): The Missing Wealth of Nations: Are Europe and the US net Debtors or net Creditors? Quarterly Journal of Economics, 128, No. 3, pp. 1321 - 1364. 